\title{
INTELLECTUAL CAPITAL DISCLOSURE: SUATU ANALISIS DENGAN FOUR WAY NUMERICAL CODING SYSTEM
}

\author{
Ihyaul Ulum \\ University of Muhammadiyah Malang \\ e-mail: ihyaul.ulum5@gmail.com
}

\begin{abstract}
The purpose of this study is to investigate the Intellectual Capital Disclosure (ICD) practice of Indonesian banking companies. IC framework used in this study is a modification of IFAC (1998) and Guthrie et al. (1999) with Bapepam-LK regulation number: Kep-431 / BL / 2012. Data were drawn from Indonesian banking companies listed on Indonesia Stock Exchange for three years, 2006, 2009, and 2012. The samples consist of 64 banks. Data analysis was performed through content analysis with weighting/scoring between 0-3, referred to the 'four way numerical coding system'. Overall, the number of ICD in the annual report increased from 2006, 2009, and 2012 except for the components of relational capital $(R C)$ which fluctuated. Viewed from the weight of the disclosure are analyzed with numerical coding system four way, it appears that the majority of IC information disclosed are in the form of a narrative.

Keywords: Intellectual capital disclosure, four way numerical coding system, Indonesian banking companies

http://dx.doi.org/10.20885/jaai.vol19.iss1.art4
\end{abstract}

\begin{abstract}
Abstrak
Tujuan dari penelitian ini adalah untuk menganalisis Pengungkapan Modal Intelektual (ICD) praktik perusahaan perbankan di Indonesia. Kerangka IC yang digunakan dalam penelitian ini merupakan modifikasi dari IFAC (1998) dan Guthrie et al. (1999) dengan nomor Peraturan Bapepam-LK: Kep-431 / BL/2012. Data diambil dari perusahaan perbankan Indonesia yang terdaftar di Bursa Efek Indonesia selama tiga tahun, 2006, 2009, dan 2012. Sampel terdiri dari 64 bank. Analisis data dilakukan melalui analisis isi dengan pembobotan/scoring antara 0-3, mengacu pada 'four way numerical coding system'. Secara keseluruhan, jumlah ICD dalam laporan tahunan meningkat dari tahun 2006, 2009, dan 2012 kecuali untuk komponen modal relasional (RC) yang mengalami fluktuasi. Dilihat dari bobot pengungkapan yang dianalisis dengan 'four way numerical coding system', tampak bahwa sebagian besar informasi IC diungkapkan dalam bentuk narasi.
\end{abstract}

Kata Kunci: Pengungkapan Modal Intelektual, four way numerical coding system, Perusahaan Perbankan Indonesia.

\section{PENDAHULUAN}

Sejak tahun 2000, para akademisi dan praktisi mulai fokus pada persoalan pengungkapan IC (intellectual capital disclosure - ICD) perusahaan di dalam laporan tahunannya (lihat misalnya: Guthrie et al. 1999; Guthrie dan Petty 2000; Goh dan Lim 2004). Definisi ICD telah diperdebatkan diantara para ahli dalam berbagai literatur (Ulum 2015a).

Guthrie dan Petty (2000) tidak menawarkan definisi ICD secara eksplisit, namun mereka menyinggung adanya fakta bahwa saat ini ICD memberikan kemanfaatan yang lebih besar dibanding di masa lalu. Terutama bagi sektor yang mempunyai karakteristik industri dominan yang kemudian mengalami perubahan, seperti dari sektor manufaktur berubah menjadi high technology, finansial dan jasa asuransi.

Bukh et al. (2001), Petty dan Guthrie (2000), dan Mourtisen et al. (2005) mengidentifikasi bahwa literatur IC dalam akuntansi terutama membahas pelaporan eksternal. Hal ini dapat dipahami karena memang pasar modal menginginkan lebih banyak informasi 
yang dapat diandalkan terkait dengan sumber daya pengetahuan yang dimiliki oleh perusahaan, dan pengungkapan IC akan mengurangi biaya transaksi dan ketidakpastian diantara pihak-pihak terkait (Tayles et al. 2007). Lebih lanjut, Bukh (2003) menyatakan bahwa pengungkapan perusahaan tentang IC menjadi bagian dari kerangka proses penciptaan nilai (value creation) dalam perusahaan.

Kebanyakan literatur mengenai IC di berbagai negara, berfokus pada pengungkapan IC dalam laporan tahunan perusahaan (Guthrie dan Petty 2000; Goh dan Lim 2004). Beberapa studi mengenai upaya untuk menjelaskan perbedaan tingkat pengungkapan IC dalam laporan tahunan (Brennan 2001; April et al. 2003; Ulum 2011), namun tidak banyak yang menggunakan uji statistik (Williams 2001; Bontis 2002, Bozzolan et al. 2003). Tingkat pengungkapan IC umumnya dinilai meng gunakan content analysis atas laporan tahunan dari sejumlah kecil sampel (perusahaan).

Mouritsen et al. (2001) menyatakan bahwa ICD dalam suatu laporan keuangan sebagai suatu cara untuk mengungkapkan bahwa laporan tersebut menggambarkan aktifitas perusahaan yang kredibel, terpadu (kohesif) serta "true and fair". Mereka merujuk pada laporan IC yang menunjukkan bahwa banyak dari literatur pengungkapan IC berdasar pada analisis tekstual atas laporan keuangan. Sangat sedikit perusahaan yang membuat laporan IC secara terpisah.

Lebih lanjut, Mouritsen et al. (2001) menyatakan bahwa ICD dikomunikasikan untuk stakeholder internal dan eksternal yaitu dengan mengkombinasikan laporan berbentuk angka, visualisasi dan naratif yang bertujuan sebagai penciptaan nilai. Bukh et al. (2001) juga menegaskan hal senada, bahwa laporan IC dalam prakteknya, mengandung informasi finansial dan non-finansial yang beragam seperti perputaran karyawan, kepuasan kerja, in-service training, kepuasan pelanggan, ketepatan pasokan, dan sebaginya.

Pengungkapan IC telah menjadi suatu bentuk komunikasi baru yang mengendalikan "kontrak" antara manajemen dan pekerja. Hal tersebut, memungkinkan manajer untuk mem- buat strategi-strategi untuk memenuhi ekspektasi stakeholder seperti investor, dan untuk meyakinkan stakeholder atas keunggulan atau manfaat kebijakan perusahaan (Ulum 2009).

Artikel ini berusaha mengembangkan suatu kerangka kerja ICD yang dibangun dengan cara memodifikasi skema yang dibangun oleh Guthrie et al. (1999), yang merupakan pengembangan dari definisi IC yang ditawarkan oleh Sveiby (1997), yang juga digunakan oleh Brennan (2001). Modifikasi dilakukan dengan menambahkan beberapa item yang diatur dalam Keputusan Ketua Badan Pengawas Pasar Modal dan Laporan Keuangan Nomor: Kep431/BL/2012 tentang Penyampaian Laporan Tahunan Emiten atau Perusahaan Publik.

\section{TINJAUAN PUSTAKA DAN PERUMUSAN HIPOTESIS}

\section{Teori Pensinyalan (Signaling Theory)}

Signaling theory pada dasarnya concern dengan penurunan asimetri informasi di antara dua pihak (Spence 2002). Teori pensinyalan berkaitan dengan bagaimana mengatasi masalah yang timbul dari asimetri informasi dalam seting sosial. Hal ini menunjukkan bahwa asimetri informasi dapat dikurangi jika pihak yang memiliki informasi dapat mengirim sinyal kepada pihak terkait. Sebuah sinyal dapat menjadi suatu tindakan yang dapat diamati, atau struktur yang diamati, yang digunakan untuk menunjukkan karakteristik tersembunyi (atau kualitas) dari signaler tersebut. Pengiriman sinyal biasanya didasarkan pada asumsi bahwa itu harus menguntungkan bagi signaler (misalnya menunjukkan kualitas yang lebih tinggi dari produk dibandingkan dengan pesaingnya) (An et al.2011).

Teori pensinyalan menyatakan bahwa perusahaan berkualitas tinggi akan cenderung memberikan sinyal keunggulan mereka kepada pasar. Pada satu sisi, sinyal akan membuat investor dan pemangku kepentingan yang lain menaikkan nilai perusahaan, dan kemudian membuat keputusan yang lebih menguntungkan bagi perusahaan (Whiting dan Miller 2008). Sebaliknya, perusahaan-perusahaan dengan kapasitas tidak terlalu bagus akan 
cenderung untuk mengungkapkan informasi yang sifatnya memang mandatory.

Pengungkapan sukarela informasi IC akan menjadi media yang sangat efektif bagi perusahaan untuk menyampaikan sinyal kualitas superior yang mereka miliki terkait kepemilikian IC yang signifikan untuk penciptaan kesejahteraan di masa yang akan datang (Guthrie dan Petty 2000, Whiting dan Miller 2008). Khususnya bagi mereka yang memiliki basis IC yang kuat, pengungkapan sukarela IC akan membedakan mereka dari perusahaan-perusahaan dengan kualitas yang lebih rendah. Seringkali diyakini bahwa pemberian sinyal tentang atribut IC, misalnya pengungkapan melalui laporan tahunan, akan menghasilan beberapa keuntungan bagi perusahaan. Misalnya meningkatnya image perusahaan, menarik investor potensial, mengurangi biaya modal, menurunkan volatilitas saham, menciptakan pemahaman tentang produk atau jasa, dan yang lebih penting adalah meningkatkan hubungan dengan para pemangku kepentingan (Vergauwen dan Alem 2005, Singh dan Van-der-Zahn 2008).

\section{Intellectual Capital}

Penelitian tentang IC telah dimulai sejak 1990an (Choong 2008). Human capital adalah fokus utama penelitian tentang IC pada masa itu, dan para peneliti menguji peran 'knowledge' dalam IC (Santoso 2011). Bahkan, studi tentang intangible assets telah dilakukan sejak tahun 1940an, dimulai oleh Davis et al. (1940) yang meneliti tentang peran intangible assets, seperti goodwill, yang merupakan nilai bagi organisasi. Belakangan, Itami dan Roehl (1987) memperkenalkan konsep tentang intangible assets sebagai invisible assets. Invisible assets meliputi sumber daya berbasis informasi seperti technological knowledge, customer knowledge, dan market knowledge (Hall 1992).

IC merupakan salah satu bidang kajian Akuntansi. Hal ini misalnya ditegaskan secara sangat jelas oleh Guthrie et al. (2012) yang menggunakan istilah Intellectual Capital Accounting (ICA) ketika mereviu 2662 artikel dari 10 jurnal internasional di bidang Akuntansi. Mereka menemukan bahwa 423 dari jumlah artikel tersebut mengkaji tentang ICA (lihat Tabel 2.1). Penegasan yang sama juga dinyatakan oleh Dumay (2014) ketika menghitung jumlah sitasi artikel-artikel IC di Journal of Intellectual Capital (JIC) dibandingkan dengan jumlah sitasi artikel yang dimuat pada 19 jurnal internasional lainnya.

Tabel 1: Artikel ICA pada Jurnal Internasional (2000-2009)

\begin{tabular}{lcccc}
\hline Nama Jurnal & $\begin{array}{c}\text { Kode } \\
\text { Jurnal }\end{array}$ & $\begin{array}{c}\text { Artikel } \\
\text { ICA }\end{array}$ & $\begin{array}{c}\text { Total } \\
\text { Artikel }\end{array}$ & $\begin{array}{c}\text { \% Artikel } \\
\text { ICA }\end{array}$ \\
\hline Jurnal 'Specialist' & & & & \\
Journal of Intellectual Capital & JIC & 297 & 313 & $94,9 \%$ \\
Journal of Human Resource Costing and Accounting & JHRCA & 48 & 84 & $57,1 \%$ \\
Total artikel ICA articles pada jurnal 'specialist' & & $\mathbf{3 4 5}$ & $\mathbf{3 9 7}$ & $\mathbf{8 6 , 9 \%}$ \\
Jurnal 'Generalist' & & & & \\
Accounting Auditing and Accountability Journal & AAAJ & 22 & 337 & $6,5 \%$ \\
European Accounting Review & EAR & 17 & 288 & $5,9 \%$ \\
Accounting Organizations and Society & AOS & 11 & 345 & $3,2 \%$ \\
Australian Accounting Review & AAR & 8 & 261 & $3,1 \%$ \\
Management Accounting Research & MAR & 5 & 210 & $2,4 \%$ \\
Accounting Forum & AF & 5 & 212 & $2,4 \%$ \\
British Accounting Review & BAR & 3 & 177 & $1,7 \%$ \\
Critical Perspectives on Accounting & CPA & 7 & 435 & $1,6 \%$ \\
Total ICA articles in generalist Journals & & $\mathbf{7 8}$ & $\mathbf{2 2 6 5}$ & $\mathbf{3 , 4 \%}$ \\
Total ICA articles in all Journals & & $\mathbf{4 2 3}$ & $\mathbf{2 6 6 2}$ & $\mathbf{1 5 , 9 \%}$ \\
\hline Sumber: Guthie et al (20)
\end{tabular}

Sumber: Guthrie et al. (2012) 
Roos et al.( 1997) menyatakan bahwa IC meliputi seluruh proses dan aset yang tidak secara normal nampak di neraca dan semua intangible assets (trademarks, patent dan brands) yang menjadi perhatian metode akuntansi modern. Sedangkan Bontis (1998) mengakui bahwa IC adalah elusive, namun ketika IC dapat ditemukan dan 'dieksploitasi', maka ia akan menjadi sumber daya baru bagi organisasi untuk dapat memenangkan persaingan.

IFAC (1998) mengklasifikasikan IC dalam tiga kategori, yaitu: (1) Organizational Capital, (2) Relational Capital, dan (3) Human Capital. Organizational Capital meliputi a) intellectual property dan b) infrastructure assets

Bontis et al. (2000) menyatakan bahwa secara umum, para peneliti mengidentifikasi tiga konstruk utama dari IC, yaitu: human capital (HC), structural capital (SC), dan customer capital (CC). Menurut Bontis et al. (2000), secara sederhana HC merepresen- tasikan individual knowledge stock suatu organisasi yang direpresentasikan oleh karyawannya. HC merupakan kombinasi dari genetic inheritance; education; experience, and attitude tentang kehidupan dan bisnis.

SC meliputi seluruh non-human storehouses of knowledge dalam organisasi. Termasuk dalam hal ini adalah database, organisational charts, process manuals, strategies, routines dan segala hal yang membuat nilai perusahaan lebih besar daripada nilai materialnya. Sedangkan tema utama dari CC adalah pengetahuan yang melekat dalam marketing channels dan customer relationship dimana suatu organisasi mengembangkannya melalui jalannya bisnis (Bontis et al. 2000). Sejumlah kajian telah dilakukan untuk menginvestigasi metode penilaian dan pengukuran IC. Tabel 2 merangkum namanama metode yang 'dianggap' sebagai metode untuk menilai dan mengukur IC.

Tabel 2: Metode Penilaian dan Pengukuran IC

\begin{tabular}{|c|c|c|c|}
\hline No. & Nama Metode & Penemu/Pengusul & Tahun \\
\hline 1. & Balanced Scorecard & Robert S. Kaplan dan David P. Norton & 1992 \\
\hline & Calculated Intangible Value & Thomas A. Stewart & 1997 \\
\hline & & David H. Luthy & 1998 \\
\hline & Citation-Weighted Patent & $\begin{array}{l}\text { Bronwyn H. Hall, Adam B. Jaffe, dan } \\
\text { Manuel Trajtenberg }\end{array}$ & 2001 \\
\hline & Holistic Value Approach & $\begin{array}{l}\text { Göran Roos, J. Roos, } \\
\text { Nicola C. Dragonetti, dan Leif } \\
\text { Edvinsson }\end{array}$ & 1997 \\
\hline & Intellectual Capital Audit & Annie Brooking & 1996 \\
\hline & Intellectual Capital-Index & Göran Roos & 1997 \\
\hline & Inclusive Value Methodology & Philip K. M'Pherson dan Stephan Pike & 2001 \\
\hline & Intangible Asset Monitor & Karl Erik Sveiby & 1997 \\
\hline & Intangibles Scoreboard & Baruch Lev & 1999 \\
\hline 10. & Intellectual Capital Benchmarking System & José Maria Viedma & 1999,2001 \\
\hline & Intellectual Capital Dynamic Value & Ahmed Bounfour & 2002 \\
\hline & Intellectual Capital Statements & Jan Mouritsen & 2001 \\
\hline & iValuing Factor & Ken Standfield & 2001 \\
\hline & Market-To-Book Ratio & Thomas A. Stewart & 1997 \\
\hline 15. & Skandia Navigator & Leif Edvinsson dan Michael S. Malone & 1997 \\
\hline 16. & Sullivan's Work & Patrick H. Sullivan & 1998,2000 \\
\hline 17. & Value-Added Intellectual Coefficient (VAIC) & Ante Pulic & 1998 \\
\hline & Value Chain Scoreboard/ Value Chain Blueprint & Baruch Lev & 2001,2003 \\
\hline & Extended VAIC & $\begin{array}{l}\text { Jamal A. Nazari dan Irene M. } \\
\text { Herremans }\end{array}$ & 2007 \\
\hline 20. & $\mathrm{iB}-\mathrm{VAIC}$ & Ihyaul Ulum & 2013 \\
\hline
\end{tabular}

Sumber: Ulum (2015a) 


\section{METODA PENELITIAN}

Unit analisis penelitian ini adalah laporan tahunan perusahaan publik sektor perbankan di Indonesia. Industri perbankan dipilih dengan pertimbangan bahwa sektor industri ini sangat ketat regulasinya sehingga cenderung untuk lebih banyak menyajikan informasi ke publik. Selain itu, menurut Firer dan Williams (2003), sektor perbankan merupakan sektor industri yang memiliki insentif IC tinggi. perusahaan terdaftar dan sahamnya aktif diperdagangkan di Bursa Efek Indonesia. Tahun pengamatan dalam penelitian ini adalah tahun 2006, 2009, dan 2012. Tahun pengamatan tidak berurutan dengan pertimbangan bahwa biasanya informasi dalam laporan tahunan akan relatif tidak banyak berbeda dalam dua tahun yang berdekatan.

Tahun 2006 dipilih karena di tahun 2006 keluar Keputusan Ketua Bapepam-LK Nomor: Kep-134/BL/2006 yang mengatur tentang kewajiban emiten untuk menyampaikan laporan tahunannya. Adanya peraturan ini tentu menjadi motivasi bagi perusahaan publik untuk menyusun dan mempublikasikan laporan tahunan secara lebih baik, lebih komprehensif, dan lebih informatif daripada tahuntahun sebelumnya. Tahun 2009 dipilih sebagai 'tahun aman' setelah pada tahun 2008 krisis keuangan melanda beberapa negara di Eropa. Meskipun diyakini bahwa krisis tersebut tidak merambah ke Indonesia, pemilihan tahun 2009 untuk memastikan bahwa pada tahun tersebut pasar modal Indonesia benar-benar 'sehat' sehingga harga saham yang terjadi merupakan refleksi dari aktivitas ekonomi. Sementara tahun 2012 dipilih dengan pertimbangan visibilitas data mutakhir yang bisa diakses.

Analisis isi (content analysis) dipilih sebaca cara untuk mengidentifikasi ICD di dalam laporan tahunan. Langkah yang dilakukan pada analisis isi dalam penelitian ini menggunakan interactive model dari Miles dan Huberman (1994). Model ini mengandung 4 komponen yang saling berkaitan, yaitu (1) pengumpulan data, (2) penyederhanaan atau reduksi data, (3) penyajian data, (4) penarikan dan pengujian atau verifikasi simpulan. Content analysis merupakan cara yang paling tepat untuk menginvestigasi praktik pengungkapan IC oleh perusahaan (Guthrie et al. 2004). Pendekatan ini telah digunakan oleh para peneliti untuk mengidentifikasi hal yang sama dengan penelitian ini (lihat misalnya: Guthrie dan Petty 2000, Brennan 2001; Williams 2001; Bozzolan et al. 2003, White et al. 2007).

Proses identifikasi ICD dilakukan dengan 4 cara sistem kode numerik (four-way numerical coding system) yang dikembangkan oleh Guthrie et al. (1999). Metode ini tidak hanya mengidentifikasi luas pengungkapan IC dari aspek kuantitas, namun juga kualitas pengungkapannya. Pengungkapan informasi IC dalam laporan tahunan diberi bobot sesuai dengan proyeksinya. Kode numerik yang digunakan adalah sebagai berikut:

$0=$ item tidak diungkapkan dalam laporan tahunan;

1 = item diungkapkan dalam bentuk narasi;

2 = item diungkapkan dahm bentuk numerik;

$3=$ item diungkapkan dengan nilai moneter.

\section{HASIL DAN PEMBAHASAN}

\section{ICD In (Intellectual Capital Disclosure Indonesia)}

Intellectual Capital Disclosure Indonesia adalah jumlah pengungkapan informasi tentang IC yang disajikan dalam laporan tahunan perusahaan. Intellectual Capital Disclosure Indonesia adalah hasil modifikasi skema yang dibangun oleh Guthrie et al. (1999), yang merupakan pengembangan dari definisi IC yang ditawarkan oleh Sveiby (1997), yang juga digunakan oleh Brennan (2001). Modifikasi dilakukan dengan menambahkan beberapa item yang diatur dalam Keputusan Ketua Bapepam dan LK Nomor: Kep-431/BL/2012 tentang Penyampaian Laporan Tahunan Emiten atau Perusahaan Publik. Dalam skema ini, IC dikelompokkan dalam 3 kategori yang terdiri dari 36 item yaitu 3 kategori dan 36 item yang dimaksud adalah sebagai berikut: kategori human capital 8 item; structural capital 15 item; dan relational capital 13 item, 15 diantaranya adalah item modifikasi, diberi kode (M). 
Modifikasi ini dilakukan karena beberapa item dalam IFAC (1998) dan Guthrie et al. (1999) cenderung merupakan pengulangan dan atau penekanan lebih lanjut dari item yang lain. Misalnya, pada komponen human capital (employee competence) terdapat item tentang work-related knowledge dan work-related competences yang sesungguhnya merupakan bagian lebih lanjut dari item 'pengetahuan karyawan'. Keputusan Ketua Bapepam dan
LK Nomor: Kep-431/BL/2012 yang dijadikan dasar dalam melakukan modifikasi merupakan dasar bagi emiten dalam menyusun laporan tahunan, sehingga modifikasi ini sesungguhnya merupakan penyesuaian ICD dengan versi Indonesia.

Tabel 3 menyajikan daftar komponen IC dalam framework ICD-In yang digunakan dalam penelitian ini.

Tabel 3: Komponen ICD 36 Item, Skala, dan Skor Kumulatif

\begin{tabular}{|c|c|c|c|}
\hline Kategori & Item Pengungkapan & Skala & Skor Kumulatif \\
\hline Human & Jumlah karyawan (M) & $0-2$ & 2 \\
\hline \multirow{7}{*}{ Capital } & Level Pendidikan & $0-2$ & 4 \\
\hline & Kualifikasi karyawan & $0-2$ & 6 \\
\hline & Pengetahuan karyawan & $0-1$ & 7 \\
\hline & Kompetensi karyawan & $0-1$ & 8 \\
\hline & Pendidikan \& pelatihan $(\mathrm{M})$ & $0-2$ & 10 \\
\hline & Jenis pelatihan terkait $(\mathrm{M})$ & $0-2$ & 12 \\
\hline & Turnover karyawan (M) & $0-2$ & 14 \\
\hline \multirow{15}{*}{$\begin{array}{c}\text { Structural } \\
\text { Capital }\end{array}$} & Visi misi (M) & $0-1$ & 15 \\
\hline & Kode etik (M) & $0-1$ & 16 \\
\hline & Hak paten & $0-2$ & 18 \\
\hline & Hak cipta & $0-2$ & 20 \\
\hline & Trademarks & $0-2$ & 22 \\
\hline & Filosofi managemen & $0-1$ & 23 \\
\hline & Budaya organisasi & $0-1$ & 24 \\
\hline & Proses manajemen & $0-1$ & 25 \\
\hline & Sistem informasi & $0-2$ & 27 \\
\hline & Sistem jaringan & $0-2$ & 29 \\
\hline & Corporate governance (M) & $0-3$ & 32 \\
\hline & Sistem pelaporan pelanggaran $(\mathrm{M})$ & $0-1$ & 33 \\
\hline & Analisis kinerja keuangan komprehensif (M) & $0-3$ & 36 \\
\hline & Kemampuan membayar utang (M) & $0-3$ & 39 \\
\hline & Struktur permodalan (M) & $0-3$ & 42 \\
\hline \multirow{13}{*}{$\begin{array}{c}\text { Relational } \\
\text { Capital }\end{array}$} & Brand & $0-1$ & 43 \\
\hline & Pelanggan & $0-2$ & 45 \\
\hline & Loyalitas pelanggan & $0-1$ & 46 \\
\hline & Nama perusahaan & $0-1$ & 47 \\
\hline & Jaringan distribusi & $0-2$ & 49 \\
\hline & Kolaborasi bisnis & $0-1$ & 50 \\
\hline & Perjanjian lisensi & $0-3$ & 53 \\
\hline & Kontrak-kontrak yang menguntungkan & $0-3$ & 56 \\
\hline & Perjanjian Franchise & $0-2$ & 58 \\
\hline & Penghargaan $(\mathrm{M})$ & $0-2$ & 60 \\
\hline & Sertifikasi (M) & $0-1$ & 61 \\
\hline & Strategi pemasaran $(\mathrm{M})$ & $0-1$ & 62 \\
\hline & Pangsa pasar $(\mathrm{M})$ & $0-2$ & 64 \\
\hline
\end{tabular}




\section{Analisis Isi (Content Analysis)}

Analisis isi dilakukan untuk mengidentifikasi pengungkapan modal intelektual (ICD) di dalam laporan tahunan perusahaan. Intellectual Capital Disclosure adalah jumlah pengungkapan informasi tentang IC yang disajikan dalam laporan tahunan perusahaan. Kategori/komponen IC yang diadopsi dalam penelitian ini adalah modifikasi skema yang dibangun oleh Guthrie et al. (1999), yang merupakan pengembangan dari definisi IC yang ditawarkan oleh Sveiby (1997).

Modifikasi dilakukan dengan menambahkan beberapa item yang diatur dalam Keputusan Ketua Bapepam dan LK Nomor: Kep-431/BL/2012 tentang Penyampaian Laporan Tahunan Emiten atau Perusahaan Publik. Dalam skema ini, IC dikelompokkan dalam 3 kategori yang terdiri dari 36 item, 15 diantaranya adalah item modifikasi, diberi kode (M). Secara umum, jumlah pengungkapan informasi IC di dalam laporan tahunan perusahaan mengalami peningkatan dari tahun 2006, 2009, dan 2012 kecuali untuk komponen relational capital (RC) yang fluktuatif. Di tahun 2012, terdapat tiga item IC yang tidak diungkapkan oleh seluruh perusahaan yaitu 'hak cipta', 'trademark', dan 'penghargaan'. Sebaliknya, terdapat 14 item yang diungkapkan oleh seluruh perusahaan, antara lain informasi tentang human capital (5 item), informasi tentang structural capital (2 item), dan informasi tentang relational capital (7 item).

Khusus untuk tahun 2012, naiknya jumlah pengungkapan topik structural capital (SC) dan relational capital (RC) dapat dipahami sebagai dampak dari keluarnya regulasi dari Bapepam-LK Nomor: Kep431/BL/2012 tentang Penyampaian Laporan Tahunan Emiten atau Perusahaan Publik dimana hampir 50\% komponen SC dan 30\% komponen RC yang digunakan dalam penelitian ini bersumber dari regulasi tersebut. Namun, untuk komponen human capital (HC) pada tahun 2012 justru mengalami penurunan jumlah informasi yang disajikan. Hal ini mengkonfirmasi bahwa regulasi tentang penyampaian laporan tahunan tidak banyak berdampak terhadap kepatuhan emiten untuk menyajikan informasi sebagaimana diatur dalam regulasi tersebut.

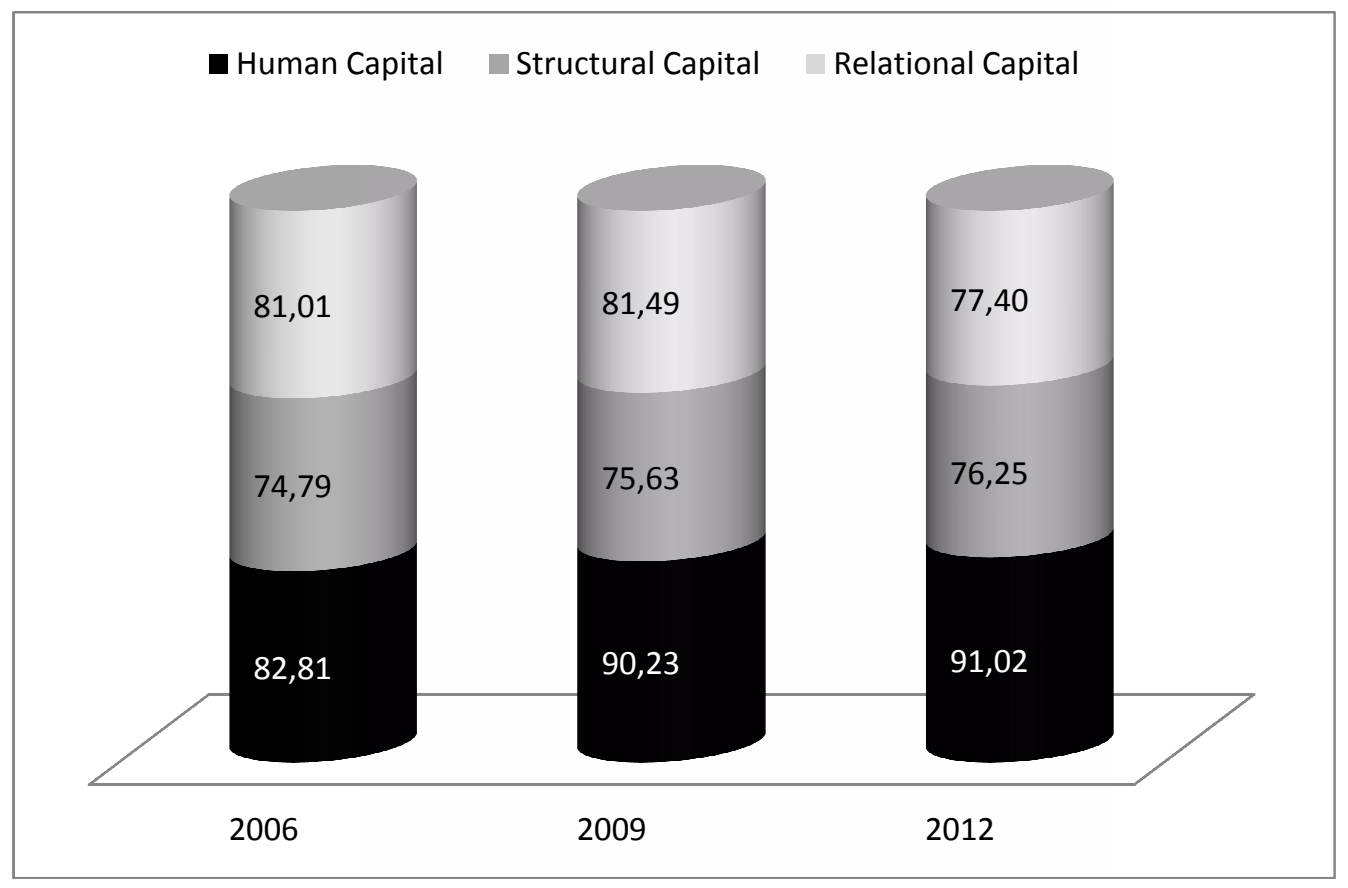

Gambar 1: Persentase Pengungkapan Informasi IC 2006, 2009, 2012 


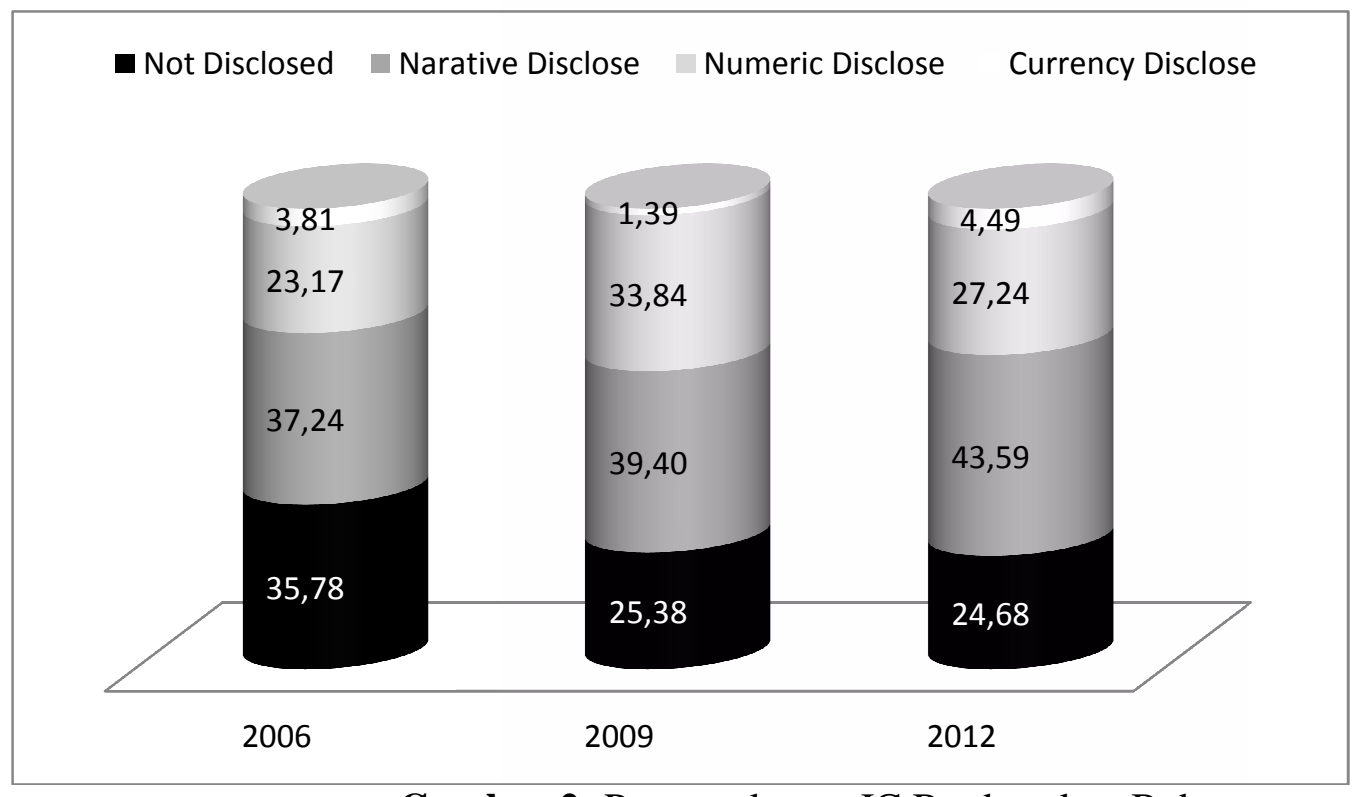

Gambar 2: Pengungkapan IC Berdasarkan Bobot

Jika dilihat dari bobot pengungkapan yang dianalisis dengan four way numerical coding system, tampak bahwa sebagian besar informasi IC diungkapkan dalam bentuk naratif. Gambar 2 menyajikan data tentang pengungkapan IC dalam laporan tahunan berdasarkan bobot selama tiga tahun pengamatan.

Berdasarkan gambar 2 diketahui bahwa pada tahun 2006, terdapat 35,78\% informasi yang tidak diungkapkan (skor=0). Jumlah ini kemudian konsisten menurun menjadi tinggal $25,38 \%$ pada tahun 2009 dan $24,68 \%$ pada tahun 2012. Sebaliknya, informasi yang diungkapkan dalam bentuk narasi (skor=1) mengalami peningkatan selama tiga tahun pengamatan. Jika pada tahun 2006 jumlahnya hanya $37,24 \%$, maka pada tahun 2009 naik menjadi 39,40\%, dan mencapai 43,59\% pada tahun 2012.

Pengungkapan informasi IC dalam bentuk angka (skor=2) mengalamai fluktuasi dari tahun ke tahun. Tahun 2012 berada pada angka 27,24\%, turun dari posisi tahun 2009 di angka 33,84\%. Namun posisi tahun 2009 lebih besar daripada tahun 2006 yang hanya $23,17 \%$. Tren yang sama juga tampak pada jenis pengungkapan dalam bentuk mata uang (skor=3). Tahun 2006, pengungkapan informasi IC dalam bentuk currency ini berada pada posisi $3,81 \%$, kemudian turun ke $1,39 \%$ pada tahun 2009, dan naik lagi pada tahun 2012 menjadi $4.49 \%$.

Secara keseluruhan, informasi IC yang diungkapkan dalam bentuk narasi mendominasi jenis pengungkapan, yakni pada kisaran $37,24 \%$ hingga $43,59 \%$. Angka ini berada di atas persentase yang seharusnya, yaitu $36,11 \%$. Sementara informasi IC yang diungkapkan dalam bentuk numerik ada pada kisaran $23,17 \%$ hingga $33,84 \%$ dari seharusnya yang mencapai $50 \%$. Sedangkan informasi IC yang disajikan dalam bentuk currency berada cukup jauh dari yang seharusnya $(13,89 \%)$, yakni antara $1.39 \%$ hingga $4,49 \%$.

Persentase informasi IC yang tidak diungkapkan (skor=0) cukup tinggi, yaitu antara $24.68 \%$ hingga $35.78 \%$. Menariknya, dari sejumlah item yang tidak diungkapkan oleh cukup banyak sampel penelitian ini adalah item-item yang sifatnya adalah mandatory dari Bapepam-LK (sekarang OJK). Misalnya, informasi tentang 'sertifikasi' (item ke 34) hanya diungkapkan oleh 6 dari 25 bank di tahun 2012. Informasi tentang 'kemampuan membayar utang' (item ke 22) hanya diungkapkan oleh 5 dari 21 bank di tahun 2009. Demikian juga informasi tentang 'turnover karyawan' (item ke 8) yang hanya diungkapkan oleh 3 dari 18 bank di tahun 2006.

Hasil penelitian ini menunjukkan bahwa terdapat kecenderungan perusahaan 
perbankan di Indonesia untuk menyajikan informasi seputar IC-nya secara ala kadarnya saja, tidak maksimal. Kebanyakan mereka merasa tidak terlalu penting melakukan upaya lain untuk memengaruhi pasar (stakeholders) melalui disclosure di dalam laporan tahunan. Mereka seolah menganggap bahwa pengungkapan informasi IC di dalam laporan tahunan justru akan menjadi competitive disanvantages, sesuatu yang tidak menguntungkan bagi perusahaan.

Jika ditelisik dari perspektif bahwa perusahaan perbankan merupakan perusahaan jasa yang sangat sensitif terhadap informasi, maka dapat dipahami ketika mereka cenderung tertutup terhadap informasi yang mereka miliki. Informasi, apalagi terkait dengan halhal penting bagi perusahaan, merupakan aset berharga bagi organisasi. Informasi tentang karyawan, apalagi tentang kualifikasi dan skill yang mereka miliki, cukup riskan untuk dibagi kepada publik. Demikian juga informasi tentang jaringan pelanggan (nasabah) yang telah berhasil dibangun.

Dalam perspektif resources based theory (Wernerfelt, 1995; Barney, 1999, 2001), kekayaan IC merupakan salah satu resources penting yang dimiliki organisasi. Pengungkapan informasi tentang IC yang terlalu detil mungkin akan membahayakan keunggulan yang dimiliki organisasi. Dengan kata lain, meminimalisir informasi IC sebagai upaya manajemen untuk menjaga keunggulan kompetitif yang telah dimiliki agar tidak ditiru oleh kompetitor. Terlebih dalam konteks perusahaan perbankan yang merupakan industri jasa. Informasi-informasi tertentu bisa jadi merupakan rahasia dari keunggulan perusahaan.

\section{SIMPULAN}

Sejauh ini, regulasi tentang bagaimana pengukuran, pengakuan, hingga pelaporan modal intelektual (IC) masih belum konklusif. Standar akuntansi yang berlaku baru sebatas mengatur tentang hal ikhwal seputar goodwill saja, yang merupakan salah satu jenis dari IC. PSAK 19 (Ikatan Akuntan Indonesia, 2012) tentang aset tak berwujud maupun IAS 38
(IASB, 2004) juga tidak secara spesifik membahas tentang IC. Oleh karena itu, maka model 'pelaporan' informasi IC melalui laporan tahunan menjadi salah satu alternatif sebelum ide tentang pembuatan intellectual capital statement (ICS) dapat terealisasi (Ulum, 2015b).

Kerangka kerja pengungkapan IC (ICD) yang ditawarkan dan digunakan dalam penelitian ini setidaknya memberikan tambahan pilihan untuk 'melaporkan' informasi seputar IC. Meskipun penelitian ini hanya memilih sektor perbankan sebagai sampel, namun kerangka kerja ICD ini dapat diterapkan untuk kajian-kajian di industri yang lain. Oleh karena itu maka penelitian-penelitian mendatang dapat mempertimbangkan untuk menganalisis pengungkapan IC dalam laporan tahunan dengan menggunakan kerangka kerja yang ditawarkan dalam paper ini.

Merujuk pada hasil penelitian ini, menarik untuk dikaji dalam penelitian mendatang tentang pengaruh faktor karakteristik organisasi dan faktor lainnya (misalnya kinerja keuangan) terhadap luas pengungkapan informasi IC di dalam laporan tahunan. Menarik juga untuk dikaji dengan media yang lain, misalnya tentang pengungkapan IC mełluiwebsiteresmi perusahaan.

Analisis dalam penelitian ini menggunakan pendekatan analisis isi (content analysis) sebagaimana disarankan oleh Miles dan Huberman (1994) dan Neuendorf (2002). Salah satu keterbatasan dan atau kelemahan yang melekat secara given dalam conten analysis adalah potensi adanya subjektivitas. Oleh karena itu maka harus dilakukan upaya untuk meminimalisir subjektivitas tersebut.

Untuk meminimalisir unsur subjektivitas, analisis isi dilakukan lebih dari satu orang. Selain peneliti, proses analisis isi dibantu oleh 4 orang enumerator, yaitu dua orang sarjana akuntansi dan 2 orang mahasiswa S2 Akuntansi. Masing-masing melakukan analisis isi terhadap seluruh data dengan mencantumkan nomor halaman laporan tahunan dari masing-masing item IC yang diungkapkan. Setelah itu, peneliti melakukan konfirmasi data hasil analisis isi dari masing- 
masing enumerator. Jika terdapat temuan yang berbeda diantara ketiganya, maka dilakukan analisis ulang terhadap item yang berbeda tersebut secara bersama-sama sehingga diperoleh kesepahaman atas item yang dimaksud.

\section{DAFTAR REFERENSI}

An, Y., H. Davey, dan I. R. C. Eggleton. 2011. Towards a comprehensive theoretical framework for voluntary IC disclosure. Journal of Intellectual Capital 12 (4): 571-585.

April, K. A., P. Bosma, dan D. A. Deglon. 2003. IC measurement and reporting: establishing a practice in SA mining. Journal of Intellectual Capital 4 (2): 165-180.

Barney, J. B. 1999. How a firms capabilities effect boundary decisions. Sloan Management Review 40 (3): 137-145.

. 2001. Is the resource-based "view" a useful perspective for strategic management research? Yes". Academy of Management Review 26 (1): 41-56.

Bontis, N. 1998. Intellectual capital: an exploratory study that develops measures and models. Management Decision 36 (2): 63-76.

. 2002. Intellectual capital disclosure in Canadian corporations. Unpublished Paper. McMaster University, Canada.

Bontis, N., W. C. C. Keow, dan S. Richardson. 2000. Intellectual capital and business performance in Malaysian industries. Journal of Intellectual Capital 1 (1): 85-100.

Bozzolan, S., F. Favotto, dan F. Ricceri. 2003. Italian annual intellectual capital disclosure: An empirical analysis. Journal of Intellectual Capital 4 (4): 543-558.

Brennan, N. 2001. Reporting and managing intellectual capital: evidence from Ireland. Artikel dipresentasikan pada International Symposium Measuring and Reporting Intellectual Capital: Experiences, Issues and Prospects, June, di Amsterdam.

Bukh, P. N. 2003. Commentary, the relevance of intellectual capital disclosure: a paradox?. Accounting, Auditing \& Accountability Journal 16 (1): 49-56.

Bukh, P. N., M. R. Johansen, dan J. Mouritsen. 2001. Constructing intellectual capital statements. Scandinavian Journal of Management 17: 87-108.

Choong, K. 2008. Intellectual capital: definitions, categorization and reporting models. Journal of Intellectual Capital 9 (4): 609-638.

Davis, F. H., T. R. Cloake, A. S. Fedde, dan H. A. Horne. 1940. Intangible assets. New York Certified Public Accountant 1 (1): 33 .

Dumay, J. C. 2014. 15 years of the journal of intellectual capital and counting: a manifesto for transformational IC research. Journal of Intellectual Capital 15 (1): 2-37.

Firer, S., dan S. M. Williams. 2003. Intellectual capital and traditional measures of corporate performance. Journal of Intellectual Capital 4 (3): 348-360.

Goh, P. C., dan K. P. Lim. 2004. Disclosing intellectual capital in company annual reports; Evidence from Malaysia. Journal of Intellectual Capital 5 (3): 500-510.

Guthrie, J., dan R. Petty. 2000. Intellectual capital: Australian annual reporting practices. Journal of Intellectual Capital 1 (3): 241-251.

Guthrie, J., R. Petty, F. Ferrier, dan R. Wells. 1999. There is no accounting for intellectual capital in Australia: review of annual reporting practices and the internal measurement of intangibles within Australian organisations. 
Artikel dipresentasikan pada International Symposium Measuring and Reporting Intellectual Capital: Experiences, Issues and Prospects, 911 June, di Amserdam.

Guthrie, J., R. Petty, K. Yongvanich, dan F. Ricceri. 2004. Using content analysis as a research method to inquire into intellectual capital reporting. Journal of Intellectual Capital 5 (2): 282-293.

Guthrie, J., F. Ricceri, dan J. Dumay. 2012. Reflections and projections: a decade of intellectual capital accounting research. British Accounting Review 44 (2): 68-82.

Hall, R. 1992. The strategic analysis of intangible resources. Strategic Management Journal 13 (2): 135.

IASB. 2004. Summary of IAS 38 www.iasplus.com. [diakses pada 22 November 2006].

IFAC. 1998. The Measurement and management of intellectual capital www.ifac.org. [diakses pada 23 November 2007].

Ikatan Akuntan Indonesia. 2012. PSAK No. 19 (revisi 2010) tentang aset tak berwujud. Jakarta: Ikatan Akuntan Indonesia.

Itami, H., dan T. W. Roehl. 1987. Mobilizing invisible assets. Cambridge: Harvard University Press.

Miles, M. B., dan A. M. Huberman. 1994. Qualitative data analysis. London: Sage Publications.

Mouritsen, J., H. T. Larsen, dan P. N. Bukh. 2001. Intellectual capital and the 'capable firm': narrating, visualising and numbering for managing knowledge. Accounting, Organizations and Society 26: 735-762.

Mourtisen, J., P. N. Bukh, dan B. Marr. 2005. A Reporting perspective on intellectual capital. Pada perspectives on intellectual capital, diedit oleh B.
Marr. Jordan Hill, Oxford, UK: Elsevier Butterworth-Heinemann.

Neuendorf, K. A. 2002. The content analysis guide book. London: Sage Publications.

Ptty, R., dan J. Guthrie. 2000. Intellectual capital literature review: measurement, reporting and management. Journal of Intellectual Capital 1 (2): 155-176.

Roos, J., G. Roos, N. C. Dragonetti, dan L. Edvinsson. 1997. Intellectual capital: Navigating in the new business landscape. Houndsmills: Macmillan Business.

Santoso, E. 2011. Intellectual capital in Indonesia: The Influence on financial performance of banking industry. Doctor of Management, University of Phoenix.

Singh, I., dan J. L. W. M. Van-der-Zahn. 2008. Determinants of intellectual capital disclosure in prospectuses of initial public offerings. Accounting and Business Research 38 (5): 409-431.

Spence, M. 2002. Signaling in retrospect and the informational structure of markets. American Economic Review 92 (3): 434-459.

Sveiby, K. E. 1997. The New organizational wealth: Managing \& measuring knowledge-based assets. Sydney: Berret-Koehler Publishers.

Tayles, M., R. H. Pike, dan S. Sofian. 2007. Intellectual capital, management accounting practices and corporate performance. Accounting, Auditing \& Accountability Journal 20 (4): 522548.

Ulum, I. 2009. Intellectual capital; Konsep dan kajian empiris. Yogyakarta: PT. Graha Ilmu.

2011. "Analisis praktek pengungkapan informasi intellectual capital dalam laporan tahunan perusahaan telekomunikasi di 
Indonesia. Jurnal Reviu Akuntansi dan Keuangan (JRAK) 1 (1): 49-56.

2013. iB-VAIC: Model pengukuran kinerja intellectual capital perbankan syariah di Indonesia. Inferensi (Terakreditasi Dikti) 7 (1): 183-204.

. 2015a. Intellectual capital: Model pengukuran, framework pengungkapan, dan kinerja organisasi. Malang: UMM Press.

2015b. Peran pengungkapan modal intelektual dan profitabilitas dalam hubungan antara kinerja modal intelektual dengan kapitalisasi pasar. Disertasi Tidak Dipublikasikan. Program Doktor Ilmu Ekonomi, Universitas Diponegoro, Semarang.

Vergauwen, P., dan F. Alem. 2005. Annual reports IC disclosures in The Netherlands, France and Germany. Journal of Intellectual Capital 6 (1): 89-104.
Wernerfelt, B. 1995. The Resource-based view of the firm: Ten years after. Strategic Management Journal 16 (3): 171-174.

White, G., A. Lee, dan G. Tower. 2007. Drivers of voluntary intellectual capital disclosure in listed biotechnology companies. Journal of Intellectual Capital 8 (3): 517-537.

Whiting, R. H., dan J. C. Miller. 2008. Voluntary disclosure of intellectual capital in New Zealand annual reports and the 'hidden value'. Journal of Human Resource Costing \& Accounting 12 (1): 26-50.

Williams, S. M. 2001. Is a company's intellectual capital performance and intellectual capital disclosure practices related?: Evidence from publicly listed companies from the FTSE 100. Journal of Intellectual Capital 2 (3): 192-203. 